\title{
Give Functionalism Another Chance
}

\author{
REVIEW By GERALD SCHNEIDER \\ Department of Politics and Management, University of Konstanz
}

International Norms and Decision Making: A Punctuated Equilibrium Analysis. By Gary Goertz. Lanham, MD: Rowman and Littlefield, 2003. 280 pp., \$75.00 cloth (ISBN: 07425-2589-9), \$29.95 paper (ISBN: 0-7425-2590-2).

One of the informal slanders leveled at the international relations literature is the reproach that the profession experiences many heroic take-offs but few safe landings. Because it exhibits a similar imbalance between theoretical ambition and empirical evidence, International Norms and Decision Making by Gary Goertz must be evaluated against this backdrop. Goertz endeavors to ground regime theory-which he equates with the theory of international norms - firmly in decision-making analysis. His rigorous treatise on the sources of international collaboration is like a first step in a long-term research project. In the book Goertz attempts to reconcile different strands in international relations theory, ranging from constructivism to formal theory. Borrowing the concept of "punctuated equilibrium" from paleontology, he tries in particular to explain the evolution of international norms with a functionalist logic. This approach is daring given the devastating criticism that functionalist arguments have received during the past decades from such eminent theorists as John Harsanyi (1969) and Jon Elster (1982). Yet, Goertz shields his argument preemptively against the rationalist objection that his model does not possess solid microfoundations, which is the standard argument of what he calls the "expected utility theorists." Specifically, Goertz contends that his model rises above this criticism because it possesses a superior predictive accuracy.

To understand the gist of Goertz's argument, we need to explore the idea of "punctuated equilibrium." This concept stems from the path-breaking work of two maverick paleontologists: Niles Eldredge and Stephen Jay Gould (1972). They forcefully argued in the 1970s that evolution proceeds in a stop-and-go rather than a gradual fashion. Goertz adapts this insight, which is disputed even among paleontologists, to questions of international and comparative politics. Specifically, he contends - in contrast to the incrementalist school of thought (Wildavsky 1975) - that in social systems, and thus also in international organization, extended periods of immobility tend to give way to sudden phases of significant change. This pattern of institutional development holds, for instance, for the European Union, in which protracted periods of institutional sclerosis follow short-lived integration breakthroughs (Schneider and Cederman 1994).

Fortunately, in his analysis of what he calls "big bang" decisions, Goertz moves quickly from the purely metaphorical level and adopts fuzzy set logic to construct actual models of institutional change. (For more information about fuzzy set logic, see Cioffi-Revilla 1981.) Yet, even though he offers some interesting empirical illustrations of such questions as international sanctions, Goertz does not systematically examine the predictive power of his functionalist model compared with the alternative expected utility framework. A comparison of the models remains purely verbal. Indeed, Goertz repeatedly sidesteps any challenge from the expected utility 
theorists by claiming that fuzzy set logic - in contrast to the dominant rationalist concepts - has found practical applications in decision making.

The main strength of International Norms and Decision Making is that it brings important theories and concepts from various disciplines together in order to give functionalist reasoning another chance in international relations theory. The book demonstrates Goertz's widespread intellectual interests, ranging from biology and engineering to the regime theory of the 1980s and 1990s. The massive examination of the literature that undergirds the book finds its expression in a multitude of quotes that occasionally distract from the main argument. Goertz correctly asserts, however, that the enthusiasm that regime theory originally instigated was unjustifiably short lived.

The main problems with the functionalist model are conceptual. Yet, because Goertz conducts no systematic comparative tests, we have no opportunity to evaluate whether or not fuzzy set logic and the notion of punctuated equilibria are fruitful for the analysis of international norms. The next step for Goertz or his colleagues is a rigorous evaluation of the competing models. As long as no empirical evidence exists, readers are likely to remain unconvinced by the way in which Goertz criticizes his bête noire: the rationalist theory of institutions. Indeed, standard models of "constitutional choice" may still be considered superior even if the predictive accuracy of the functionalist model were much better than that of a rationalist model. In comparing competing models, it is quite common that "rules of thumb" perform better than sophisticated analytical frameworks. Today's weather might, for example, be a good predictor of tomorrow's weather. Yet, we do not learn anything from such a naive model about what causes different weather patterns.

This reservation should caution us against the wholehearted use of fuzzy set logic and other tools that might be useful for prediction but do not rest on a convincing causal mechanism. If one does not want to buy into the standard rationalist model, Peyton Young's (1993, 1998) evolutionary model could, for instance, lay the foundation for an intersubjectively understandable theory of norms or, in Young's terminology, "conventions." This theory shows how societies converge toward one behavioral pattern in the long run and why less plausible potential equilibria are discarded. Curiously, Young's work and other articles in evolutionary game theory are not mentioned by Goertz. But one does not even have to drop the assumption of strategic rationality completely. Many formal models, including the aforementioned work by Gerald Schneider and Lars-Erik Cederman (1994), boil down to the expectation that the pattern of organizational change is punctuated rather than gradual.

Because Goertz devotes so much energy to conceptual discussions rather than the comparative evaluation of his new model in International Norms and Decision Making, it remains unclear how successful the bold attempt to build a solid functionalist theory of institutions and regimes will be. In short, a soft landing is not yet in sight for the "punctuated equilibrium model." Nonetheless, the functionalist model that Goertz has built is so solid that we can hope to reach some empirical terrain in a sequel to this impressive theoretical tract.

\section{References}

Coffi-Revilla, Claudi. (1981) Fuzzy Sets and Models of International Relations. American Journal of Political Science 25:129-159.

Eldredge, Niles, and Stephen Jay Gould. (1972) Punctuated Equilibria: An Alternative to Phyletic Gradualism. In Models in Paleobiology, edited by T. J. M. Schopf. San Francisco: Freeman, Cooper.

Elster, Jon. (1982) Marxism, Functionalism, and Game Theory: The Case for Methodological Individualism. Theory and Society 11:453-482. 
Harsanyi, John C. (1969) Rational Choice Models of Political Behavior vs. Functionalist and Conformist Theories. World Politics 21:513-548.

Schneider, Gerald, and Lars-Erik Cederman. (1994) The Change of Tide in Political Cooperation: A Limited Information Model of European Integration. International Organization 48:633-662.

Wildavsky, Aron. (1975) Budgeting: A Comparative Theory of Budgetary Process. Boston: Little, Brown. Young, H. PEYTON. (1993) The Evolution of Conventions. Econometrica 61:57-84.

Young, H. Peyton. (1998) Individual Strategy and Social Structure: An Evolutionary Theory of Institutions. Princeton: Princeton University Press. 